\title{
Nasalis típusú extranodalis natural killer T-sejtes lymphoma hazai előfordulása és kezelésével szerzett tapasztalatok
}

\author{
Bakos Annamária dr. ${ }^{1}$ - Szomor Árpád dr. ${ }^{4}$ \\ Schneider Tamás dr. ${ }^{5}$ - Miltényi Zsófia dr. ${ }^{6}$ - Marton Imelda dr. ${ }^{2}$ \\ Borbényi Zita dr. ${ }^{2}$ - Pammer Judit dr. ${ }^{4}$ - Krenács László dr. ${ }^{3}$ \\ Bagdi Enikő dr. ${ }^{3}$. Piukovics Klára dr. ${ }^{2}$ \\ Szegedi Tudományegyetem, Általános Orvostudományi Kar, ${ }^{1}$ Nukleáris Medicina Intézet, \\ ${ }^{2}$ II. Belgyógyászati Klinika és Kardiológiai Központ, Hematológiai Osztály, \\ ${ }^{3}$ Daganatpatológiai és Molekuláris Diagnosztikai Laboratórium, Szeged \\ ${ }^{4}$ Pécsi Tudományegyetem, Általános Orvostudományi Kar, Klinikai Központ, I. Belgyógyászati Klinika, Pécs \\ ${ }^{5}$ Országos Onkológiai Intézet, Budapest \\ ${ }^{6}$ Debreceni Egyetem, Általános Orvostudományi, Belgyógyászati Intézet, Hematológiai Tanszék, Debrecen
}

Bevezetés: Az extranodalis nasalis típusú natural killer/T (NK/T) sejtes lymphoma (ENKTL) a T-sejtes lymphomák egyik ritka agresszív megjelenésű formája, amely elsősorban sinonasalis és nasopharynx kiindulású. Bár előfordulása ritka a fejlett nyugati országokban, kezelése a hagyományos, agresszív lymphomákban alkalmazott antraciklintartalmú kemoterápiával csekély hatékonyságú.

Célkitüzés: ENKTL-esetek előfordulása hazai hematológiai centrumok által gondozott non-Hodgkin-lymphomás betegek között.

Módszer: A szerzők négy magyarországi hematológiai centrumban 2003-2015 között kezelt 20 ENKTL-beteg klinikai adatait elemezték. A betegek között 12 férfi és 8 nő volt, medián életkor 49,5 év (22-84 év).

Eredmények: Tíz esetben a betegség lokalizált (I-II. stádiumban) volt a diagnózis idején. Kemoterápiás kezelésben részesült 17 beteg (11 CHOP, CHOP-szerü, kettő hyper-CVAD, egy ProMACECytaBom, egy SMILE, kettő egyéb), amelyet hat esetben érintett mezős besugárzással (IFRT) egészítettek ki (40-46 Gy). Az első vonalbeli kezelésre kilenc beteg komplett (CR), három parciális remisszióba (PR) került, három progrediált, két esetben stabil volt a betegség. A medián követési idő 32 (3-113) hónap volt. Öt beteg progresszió, recidíva miatt második vonalban újabb kezelésben részesült (kettő DHAP, egy VIM, egy hyper-CVAD, egy ProMACECytaBom). Második vonalbeli kezelésre CR nem jött létre egy betegben sem. Két esetben első CR-ben autológ őssejt-transzplantáció történt. Következtetés: Az ENKTL kezelésében hatékonyabbak a nem antraciklintartalmú kemoterápiás kezelések. Elsősorban L-aszparagináz-alapú kombinált kemoterápia és egyidejű vagy szekvenciális kemo-radioterápia alkalmazásával a túlélés és CR aránya javítható.

Orv Hetil. 2017; 158(41): 1635-1641.

Kulcsszavak: extranodalis NK/T sejtes lymphoma, nasalis típus, kezelés, prognózis

\section{Incidence and treatment of extranodal natural killer/T-cell lymphoma, nasal type. Hungarian experiences}

Introduction: Extranodal natural killer/T $(\mathrm{NK} / \mathrm{T})$ cell lymphoma, nasal type (ENKTL) represents a rare subtype of T-cell lymphomas with aggressive clinical behavior according to WHO 2016 classification.

Aim: ENKTL has distinctive geographic distribution with higher incidence in Asia and Latin America ( $10 \%$ of all non-Hodgkin lymphoma cases), than in Europe and North America $(<1 \%)$. ENKTL tipically origins from nasopharynx and upper aerodigestive tract. Anthracycline-based chemotherapy regimens are largely ineffective in the treatment of ENKTL. 
Method: Our aims were to evaluate the incidence and treatment strategies of ENKTL patients in Hungarian Haematological Centres between 2003 and 2015. Altogether 20 patients with ENKTL were treated in the 4 haematological hospitals (male:female ratio 12:8, with median 49.5 years of age).

Results: Ten patients had localized (stage I-II) disease at the time of the diagnosis. Seventeen patients were treated with chemotherapy (11/CHOP, CHOP-like, 2/HyperCVAD, 1/ProMACECytaBom, 1/SMILE, 2/others), which was completed with involved-field radiation therapy (IFRT) (40-46 Gy) in 6 cases were used. After first-line therapy 9 patients achieved complete remission (CR), 3 patients had partial remission (PR), 3 patients had progressive disease (PD), and 2 patients had stable disease (SD). Median follow-up was 32 (3-113) months. Five patients received second-line therapy for progressive or recurrent disease [2/DHAP, I/VIM, I/HyperCVAD, I/ProMACECytaBom]. None of the patients achieved CR after second-line therapy. Two patients have undergone autologous hematopoietic stem cell transplantation (HSCT) after the first CR

Conclusion: ENKTL treatment is more effective with nonanthracycline-containing regimens. L-asparaginase containing chemotherapy and concurrent or sequential chemo-radiotherapy improves survival and CR rates.

Keywords: extranodal NK/T-cell lymphoma, nasal type, treatment, prognosis

Bakos A, Szomor Á, Schneider T, Miltényi Zs, Marton I, Borbényi Z, Pammer J, Krenács L, Bagdi E, Piukovics K. [Incidence and treatment of extranodal natural killer/T-cell lymphoma, nasal type. Hungarian experiences]. Orv Hetil. 2017; 158(41): 1635-1641.

(Beérkezett: 2017. augusztus 2.; elfogadva: 2017. szeptember 4.)

\section{Rövidítések}

CCRT $=$ concurrent chemoradiotherapy; $\mathrm{CHOP}=\mathrm{cyc}$ lophosphamid, doxorubicin, vincristin, prednisolon; $\mathrm{CR}=$ (complete remission) komplett remisszió; $\mathrm{CT}=$ (computed tomography) komputertomográfia; DeVIC = dexamethason, etoposid, iphosphamid, carboplatin; DHAP $=$ dexamethason, cisplatin, cytarabin; DLBCL = diffúz nagy B-sejtes lymphoma; DNS = dezoxiribonukleinsav; EBV = Epstein-Barr-vírus; ENKTL = extranodalis NK/T sejtes lymphoma; GELOX = gemcitabin, L-aszparagináz, oxaloplatin; hyper-CVAD = cyclophosphamid, vincristin, doxorubicin, dexamethason, methotrexat és cytarabin; IFRT $=$ (involved-field radiotherapy) érintett mezős besugárzás; IPI = (International Prognostic Index) nemzetközi prognosztikai index; $\mathrm{LDH}=$ laktátdehidrogenáz; LVP = L-aszparagináz, vincristin, prednisolon; MDR = multidrog-rezisztencia; NHL = non-Hodgkin-lymphoma; OS $=($ overall survival $)$ teljes túlélés; $\mathrm{PD}=$ (progressive disease $)$ progresszív betegség; PET-CT $=$ (positron emission tomography-computed tomography) pozitron emissziós tomográfiakomputertomográfia; PFS $=($ progression-free survival $)$ progressziómentes túlélés; PINK $=$ (prognostic index for NK/T-cell lymphoma) prognosztikai index NK/T sejtes lymphomában; ProMACECytaBom = cyclophosphamid, doxorubicin, etoposid, cytarabin, bleomycin; $S D=$ (stable disease) stabil betegség; SMILE = dexamethason, methotrexat, iphosphamid, Laszparagináz, etopozid; vincristin, methotrexat, prednisolon; VIDL = etoposid, iphosphamid, dexamethason, L-aszparagináz; VIM = etoposid, iphosphamid, methotrexat; VIPD = etoposid, iphosphamid, cisplatin, dexamethason; WHO = World Health Organization

Az extranodalis nasalis típusú natural killer/T (NK/T) sejtes lymphoma (ENKTL) a T-sejtes lymphomák egyik ritka, agresszív megjelenésű formája $[1,2]$. A 2016-os World Health Organization (WHO) lymphomaklasszifikációjában az Epstein-Barr-vírus- (EBV-) pozitív ext- ranodalis NK/T sejtes lymphomaként szerepelnek [2, 3]. Az ENKTL elófordulását tekintve jellegzetes heterogén geográfiai megoszlást mutat. Távol-keleten és LatinAmerikában az összes non-Hodgkin-lymphoma (NHL) 10\%-át teszi ki, míg Észak-Amerikában és Európában kevesebb mint $1 \%$-át $[4,5]$. Incidenciája Délkelet-Ázsiában 5,2\%, Közép- és Dél-Amerikában 3\%, míg a fejlett nyugati országokban előfordulása ritkább $(0,3 \%)$ [4-7]. Az NK/T sejtes lymphomák szinte kizárólagosan nem nyirokcsomó-kiindulásúak. Klinikailag három megjelenési formája lehet:

1. A nasalis kiindulású ENKTL a leggyakoribb előfordulású $(80 \%)$. Lokalizációját tekintve megjelenhet az orrüregben, nasooropharynxban, a Waldeyer-gyúrü részeiben, valamint a felső légutakban. A tumor angioinvazív, a környező szövetek destrukcióját okozza (1.ábra). Ritka esetben már kezdetben, a betegség megjelenésekor rapidan disszeminálódhat, bőrben, gastrointestinalis traktusban, herében és a nyaki nyirokcsomókban jelenhet meg. 2. A nem nasalis NK/T sejtes lymphoma elsődleges kiindulási helye a bőr, here, gastrointestinalis traktus, izom, nyálmirigyek (az esetek 20\%-a). A nasalis és primer extranasalis forma elkülönítésére leginkább alkalmas a 18-FDG-PET/CT, hiszen a betegség FDG-avid. Perifériás vér érintettsége esetén agresszív NK-sejtes leukaemiának/lymphomának nevezik, amely a 3. és egyben legritkább megjelenési forma $[2,8]$. Immunfenotípusukat tekintve CD2-, citoplazmatikus CD3 $\varepsilon^{-}$, CD56-pozitívak, felszíni CD3-negatívak, citotoxikus molekulákat (granzyme B, perforin, TIA-1 [T-cell intracellular antigen-1] expresszálnak $[1,2]$ (2. ábra). Az NK/T sejtes lymphomában ismeretes az Epstein-Barr-vírus (EBV) patogenetikai szerepe. A vírus klonális episomalis formában van jelen, a virális dezoxiribonukleinsav (DNS) nem 


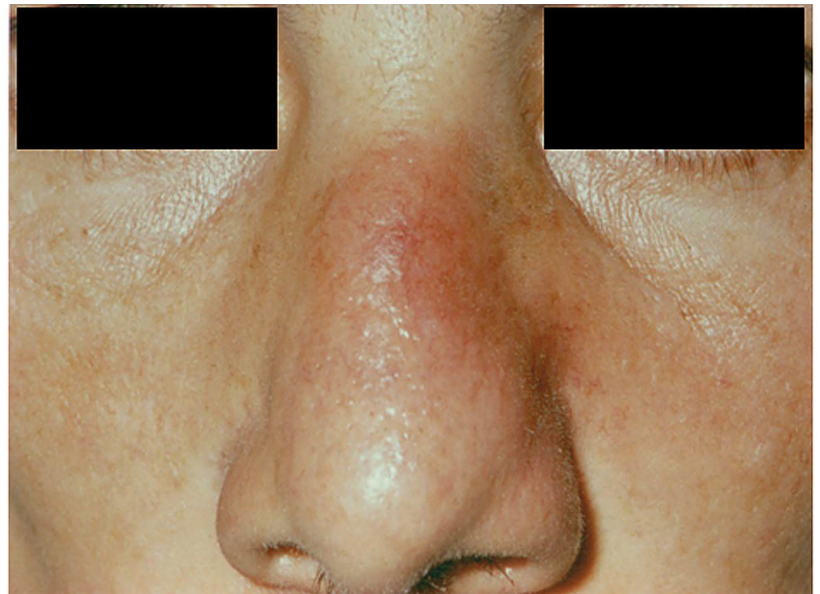

1. ábra

Nasalis típusú extranodalis NK/T sejtes lymphoma klinika megjelenése. Az orrcsont destruált, felette a bőrpír látható (saját esetünk)

integrálódik a gazdaszervezet genomjába $[2,9]$. A plazma-EBV-DNS kvantifikálása az NK/T sejtes lymphoma elsődleges diagnózisában, terápiára adott válaszban, valamint a minimális residualis betegség diagnózisában prognosztikai értékü [10]. Az ENKTL kezelésében, hasonlóan más típusú agresszív lymphomák kezeléséhez, a tradicionálisan alkalmazott antraciklintartalmú kezelés, mint a CHOP (cyclophoshamid, doxorubicin, vincristin, prednisolon) vagy CHOP-szerü protokollok kevésbé bizonyultak hatékonynak. Lokalizált ENKTL esetén CHOP-kezelés és az azt követő érintett mezős (IFRT) besugárzás hatására az ötéves teljes túlélés (OS) nem éri el az 50\%-ot. Ez elsôsorban annak tulajdonítható, hogy az NK-sejtek multidrog-rezisztenciája (MDR), P-glikoprotein expressziója magas, amely kemorezisztenciát eredményez $[11,12]$.

\section{Betegek és módszer}

Négy magyarországi hematológiai centrumban 20032015 között kezelt 20 ENKTL-beteg klinikai adatait elemeztük retrospektíve. A kezelés megkezdése előtt a betegeknél minden esetben fizikális vizsgálat, teljes vérkép, vérkémiai (vese, májfunkció, LDH) vizsgálatot, valamint képalkotó vizsgálatokat (orrmelléküreg, nyak, mellkas, has és kismedencei komputertomográfia [CT]) végeztünk. Mivel a diagnózis felállítása az első betegek-
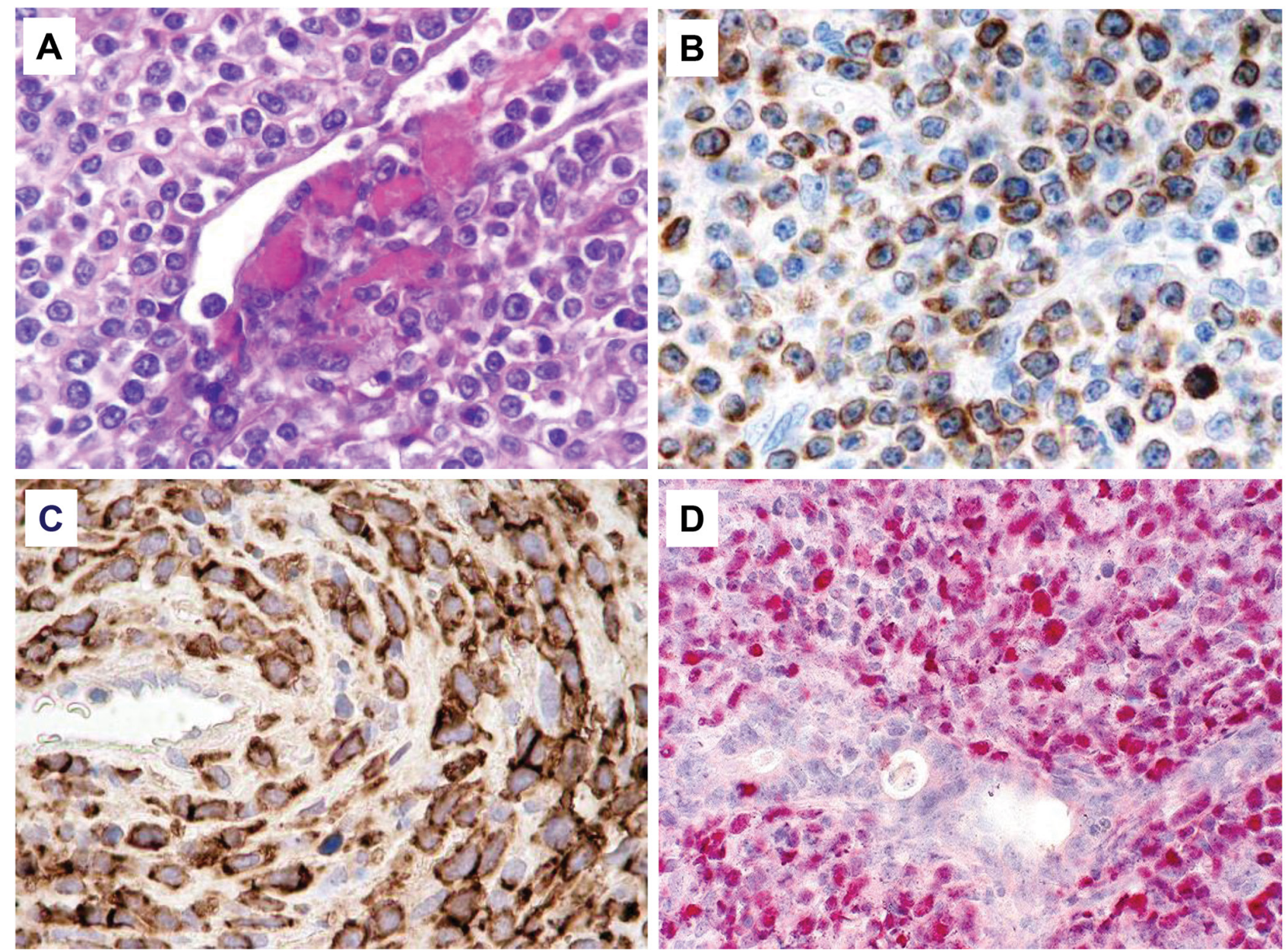

2. ábra

A nasalis típusú extranodalis NK/T sejtes lymphoma jellegzetes morfológiai megjelenése. A Angiodestruktív lymphomás infiltrátum (H\&E festés). B A daganatsejtek cytoplasmaticus CD3 é és erôs CD56 membrán $(\mathbf{C})$-pozitivitást mutatnak (B és C immunoperoxidáz immunhisztokémia). D A daganatsejtek egyöntetű EBV-pozitivitást mutatnak (EBER in situ hibridizáció). Nagyítások: A, B és C × 400, D × 200 
nél 2003-ban volt, amikor a PET-CT-t még nem alkalmaztuk széles körben non-Hodgkin-lymphomás betegek stádiumbesorolásában, így ez a vizsgálat nem történt minden esetben. Stádiumbesorolás az Ann Arbor-i stagingrendszer alapján történt. Ellenőrző CT/PET-CT vizsgálatot a reagálás megítélésére kezelés közben, illetve annak befejeztével vagy recidíva, progresszió gyanúja esetén végeztünk. A betegek prognózisának elörevetítésében az agresszív lymphomákban alkalmazott nemzetközi prognosztikai indexet (IPI) használtuk. Az IPIscore meghatározásában szerepet játszó tényezők az életkor, betegség stádiuma, extranodalis lokalizáció száma, LDH, klinikai állapot, amelyek alapján négy csoport (alacsony, alacsony-intermedier, magas-intermedier és magas rizikójú) különíthető el.

\section{Eredmények}

A vizsgált időszakban 20 elsődleges nasalis kiindulású ENKTL-beteget észleltünk, 12 férfi, nyolc nő, medián életkor 49,5 év (22-84 év). A betegek 75\%-a 60 év alatti életkorú volt. Minden beteg kaukázusi népcsoportba tartozott. Három beteg a kezelés megkezdése előtt elhunyt. Az Ann Arbor-i stádiumbeosztás szerint a 17 értékelhető beteg közül a diagnózis idején 10 (59\%) esetben a betegség lokalizált (I-II. stádiumú) volt, hét (41\%) beteg pedig előrehaladott (III-IV.) stádiumban került diagnózisra távoli érintettséggel (négy esetben leukaemiás vérkép, csontvelői érintettség, egy-egy esetben emlő-, bőr- és hereinfiltrációval). A betegek $82 \%$-a alacsony, illetve alacsony-közepes IPI-score-ral (nemzetközi prognosztikai index) bírt a kezelés megkezdése előtt. Medián követési idő 32 (3-113) hónap volt. A betegek klinikai adatait az 1. táblázat mutatja.

\section{Kezelés és kezelésre adott válasz}

Első vonalbeli kezelésként a leggyakrabban CHOP, CHOP-szerû kezelésben részesültek a betegek (11/17, $65 \%)$. Hat betegnél más típusú kombinált kemoterápiás kezelést alkalmaztunk (kettő hyper-CVAD, egy ProMACE-CytaBOM, egy nagy dózisú methotrexat + szteroid, egy L-aszparagináz-tartalmú, SMILE). Egy idős beteg pedig palliatív céllal cyclophosphamid-monoterápiát kapott. Hat beteg esetében a kemoterápiát IFRT-besugárzással egészítettük ki (2. táblázat). A radioterápia átlagos dózisa 40 Gy volt. Két betegnél a CHOP mellett intrathecalis methotrexatkezelést is alkalmaztunk (2. táblázat). Két beteg esetében végeztünk autológ őssejt-transzplantációt első komplett remisszióban BEAM-kondicionálást követően.

A 17, kezelésben részesülő beteg közül 12 (71\%) reagált az első vonalbeli kezelésre, komplett remisszióba (CR) került kilenc (53\%), parciális remisszióba három (18\%). Három esetben a betegség progressziót mutatott (PD), két esetben pedig stabil állapotot (SD) észleltünk. Nyolc beteg meghalt egy éven belül relapsus vagy az
1. táblázat |A betegek klinikai jellemzői

\begin{tabular}{ll}
\hline Betegek száma (értékelhető) & $20(17)$ \\
\hline Medián életkor, év (szórás) & $49,5(22-84)$ \\
60 év alatti betegek száma (\%) & $15(75 \%)$ \\
\hline Nemek szerinti megoszlás & $12(60)$ \\
Férfi (\%) & $8(40)$ \\
Nő (\%) & 10 \\
\hline Stádium (Ann Arbor szerint) & 7 \\
Lokalizált (I-II.) stádium & $32(3-113)$ \\
\hline Előrehaladott (III-IV.) stádium
\end{tabular}

2. táblázat |Az ENKTL-betegek kezelése és a kezelésre adott válasz

\begin{tabular}{lc}
\hline Első vonalbeli kezelés & Betegek száma, $\mathrm{n}=17(\%)$ \\
\hline Kemoterápia & $11(65)$ \\
CHOP/CHOP-szerű & 2 \\
Hyper-CVAD & 1 \\
SMILE & 1 \\
ProMACECytaBom & 2 \\
Egyéb & 6 \\
Kombinált (kemo-radio terápia) & \\
\hline Kezelésre adott válasz & Betegek száma, n = $17(\%)$ \\
\hline Komplett remisszió & $9(53)$ \\
Parciális remisszió & $3(18)$ \\
Nem reagáló/progresszió & $3(18)$ \\
Stabil betegség & $2(11)$ \\
\hline
\end{tabular}

*Öt beteg CHOP-, egy beteg SMILE-kezelés kiegészítéseként.

CHOP = cyclophosphamid, doxorubicin, vincristin, prednisolon; hyper-CVAD = cyclophosphamid, vincristin, doxorubicin, dexamethason, methotrexat és cytarabin; ProMACECytaBom = cyclophosphamid, doxorubicin, etoposid, cytarabin, bleomycin; SMILE = dexamethason, methotrexat, iphosphamid, L-aszparagináz, etoposid; vincristin, methotrexat, prednisolon

alapbetegség progressziója következtében. Öt beteg progresszió, illetve recidíva miatt második vonalban újabb kezelésben részesült (kettő DHAP, egy VIM, egy hyper-CVAD, egy ProMACECytaBom). Második CR-t egyetlen beteg esetében sem lehetett elérni. Az első vonalbeli kezelést követően öt beteg folyamatos CR-ben van. A különböző kezelési lehetőségek (kemoterápia, kemo-radio terápia) és a túlélés között statisztikai értékelés az alacsony betegszám miatt nem történt.

\section{Megbeszélés}

Az ENKTL agresszív lefolyású hematológiai malignitás. A kezelést megnehezíti az NK-sejtek magas MDR P-glikoprotein-expressziója, amely jelentős szerepet játszik a kemorezisztenciában [11]. Kezelésében a tradicionálisan 
alkalmazott antraciklintartalmú protokoll (CHOP) csekély terápiás hatékonyságot mutat, szemben az agresszív B-sejtes lymphomákkal (elsősorban diffúz nagy B-sejtes lymphoma [DLBCL] kezelésében) [11, 12]. A betegség ritka előfordulása miatt kevés átfogó tanulmány áll rendelkezésre, amelyben a különböző kemoterápiás kombinációk hatékonysága összehasonlítható lenne. Első vonalbeli kezelésként lokalizált I. stádiumú betegség esetén kezdetben csak sugárterápiát alkalmaztak változó dózisban (45-60 Gy), azonban a besugárzási mezőn kívül elfogadhatatlanul magas arányban fordult elő a betegség megjelenése. Hatékonyabb kemoterápiás kombinációk váltak szükségessé, és bevezették az egyidejü kemo-radio terápiát, valamint a szekvenciális és szendvicsstratégiát. Az I-II. stádiumú ENKTL kezelésénél retrospektív vizsgálat alapján összehasonlították a csak radioterápiával, kemoterápiával vagy ezek kombinációjával elért ötéves progressziómentes (PFS) és teljes túlélést (OS) [13]. Tse és mtsai megállapították, hogy az egyébként radioszenzitív lymphomatípus első vonalbeli irradiációjában elért kedvező eredmény mellett szisztémás relapsus lehetősége áll fenn, így az önmagában nem javasolt [13]. Yangés mtsai retrospektív, multicentrikus tanulmányuk alapján IPI low-risk, 60 év alatti I. stádiumú betegcsoporton belül az ötéves PFS 79,2\%, az OS 88,8\% volt. Annak ellenére, hogy a betegség lokalizált volt, mégis jelentős számban figyeltek meg relapsust [14]. Agresszív lymphomákban, elsősorban DLBCL-ben alkalmazott IPIscore az ENKTL-betegek prognózisának precíz előrejelzésében bizonyos korlátokat mutatott. A lokalizált ENKTL-esetek egy részét az alacsony vagy alacsony-közepes csoportba sorolta. Ezenkívül nem volt egységes álláspont a tekintetben, hogy hogyan határozzák meg ENKTL-betegekben az érintett extranodalis régiók számát [15]. A betegség kimenetelének meghatározására új score-rendszert, az NK/T sejtes lymphoma prognosztikus index bevezetését (NK-PI) javasolták 2006-ban, amely a konvencionális kemoterápiában (például CHOP) részesülő betegeket a $\mathrm{B}$-tünetek, emelkedett $\mathrm{LDH}$, előrehaladott (III-IV.) stádium és regionális (nyaki) nyirokcsomók érintettsége alapján négy rizikócsoportba sorolta [16]. Ennek megfelelően az ötéves teljes túlélés NK-PI $1 / 2 / 3 / 4$ rizikócsoportokban $81 / 64 / 34 / 7 \%$ volt [16]. A nem antraciklintartalmú kemoterápiás kezelésben részesülő ENKTL-betegek számára (besugárzással kiegészítve vagy a nélkül) 2016-ban újabb prognosztikai rendszert alakítottak ki - PINK (prognosztikai index NK/T sejtes lymphomában) és PINK-E (PINK-EBV). A két új rendszer figyelembe veszi a 60 év feletti életkor, előrehaladott (III-IV.) stádium és távoli nyirokcsomóérintettség (axillaris, infraclavicularis, mediastinalis) mellett a nem nasalis tumort (PINK) és a keringő EBVDNS-szintet (PINK-E) [17]. A PINK-score ezzel bevezetésre került az NK-PI score helyett [18].

\section{Új tipusú kemoterápiás protokollok} és sugárterápia alkalmazása lokalizált betegség elsö vonalbeli kezelésében

Néhány klinikai vizsgálat eredménye is azt igazolta, hogy a kemoterápia és sugárkezelés együttes alkalmazásakor (CCRT) jobb eredmények érhetók el. A platinatartalmú kemoterápiás szerek érzékenyítik a szolid tumort a sugárterápiára, 50 Gy irradiáció, három ciklus kétharmad dózisú DeVIC mellett a CR 75\%, az ötéves OS 73\%, PFS 67\% [6]. Egy másik tanulmány szerint 40 Gy sugárdózis heti $30 \mathrm{mg} / \mathrm{m}^{2}$ cisplatin után három ciklus VIPD alkalmazásával a CR-arány, hároméves OS és PFS tovább javítható, a szisztémás relapsus előfordulása pedig csökkenthető [19]. 2003-ban Matsumoto és mtsai ENKTL autológ őssejt-transzplantációt követő relapsusának sikeres L-aszparagináz-kezeléséről számoltak be [20]. Ezt követően Jaccard és mtsai, valamint Yamaguchi és mtsai az L-aszparagináz különböző kemoterápiás protokollokba való beépítésével nagymértékben javuló összreagálást (OR) és CR-arányt figyeltek meg (OR $87 / 80 \%$, CR $47 / 50-60 \%)$ nyugat-európai és távol-keleti betegcsoportban [21, 22]. A kombinált kemo-radio terápia után (40 Gy sugárdózis) L-aszparagináz-tartalmú VIDL mellett kezelt I-II. stádiumú betegek esetében a CR $87 \%$, az ötéves OS 60\%, PFS 73\% [23]. Az egymást követő úgynevezett szekvenciális kemo- és radioterápia alkalmazásával szintén hasonlóan jó eredmények érhetőek el. Fázis II. tanulmány alapján I. és II. stádiumú NK/T sejtes lymphomás betegek esetében az LVP-t és radioterápiát a szendvicsprotokoll szerint alkalmazva az ötéves OS és PFS 64\% volt [24]. Egy másik, L-aszparagináz-tartalmú kombináció, a GELOX kemoterápia és sugárterápia szendvicsprotokoll szerinti alkalmazása során CR $74 \%$, ötéves OS $85 \%$, PFS $74 \%$ volt [25]. Összefoglalva, ezen nem antraciklintartalmú CCRT kezelési típus, valamint a szekvenciális kemo- és radioterápia az I. és II. stádiumú NK/T sejtes lymphomás betegek első vonalbeli kezeléseként jó eredménnyel alkalmazhatók.

\section{Elörehaladott stádiumú betegség elsö vonalbeli kezelése}

Előrehaladott III. és IV. stádiumú NK/T sejtes lymphomák kezelésében is a nem antraciklintartalmú kemoterápia alkalmazandó. L-aszparagináz-tartalmú SMILE hatékonyságát vizsgálták 20, IV. stádiumban lévő betegen, két ciklus kemoterápia után CR 40\%, egyéves OS és PFS $45 \%$ volt [22]. Huszonhat, SMILE-kemoterápiával kezelt beteg retrospektív vizsgálata alapján a betegek 53,8\%-a került CR-be, ötéves OS $47,4 \%$, négyéves betegségmentes túlélés (DFS) elérte a 60\%-ot [26]. 


\section{Relapsus vagy refrakter betegség kezelése}

Azon betegek, akik első vonalbeli terápiaként antraciklintartalmú vagy egyéb nem L-aszparagináz-tartalmú kemoterápiás kezelésben részesültek, a SMILE vagy más L-aszparagináz-tartalmú kombináció eredményes lehet. Retrospektív tanulmányban 44 beteg túlélését vizsgálták. A betegek első vonalbeli kezelésként nem kaptak Laszparaginázt, majd SMILE szerint kezelték őket. A betegeknél a komplett remisszió 66\%, ötéves OS 52,3\%, négyéves DFS 68,2\% volt. Hasonlóan jó eredményt mutat a relapsus kezelésében L-aszparagináz, methotrexat és dexamethason kombinációja $[8,26]$. Az NK/T sejtes lymphomás esetek 40\%-ában a daganatsejtek CD30-pozitívak, ami lehetővé teszi a szelektív anti-CD30 antitest brentuximab vedotin mint új szer alkalmazását L-aszparagináz-tartalmú kezelés eredménytelensége esetén [26].

\section{Autológ össejt-transzplantáció}

62 betegen végzett retrospektív tanulmány szerint az első CR-ben végzett autológ őssejt-transzplantáció (ASCT) eredményességét vizsgálták. A betegek 82,3\%-a L-aszparagináz-alapú indukciós kemoterápiát kapott az ASCT-t megelőzően, 43,5\%-a sugárterápiában is részesült. ASCT-t követően a CR aránya lokalizált stádiumú betegségben $90,3 \%$, elörehaladott stádiumban pedig $65,5 \%$ volt. A transzplantációval összefüggő mortalitás 1,6\% volt. A korai stádiumú betegeknél hároméves OS 67,6\%, PFS 64,5\%, az előrehaladott stádiumú betegeknél OS 52,3\%, PFS 40,1\%-nak bizonyult [27].

\section{Következtetés}

Az ENKTL kezelésében a betegség kiterjedtségétől függően, valamint az új prognosztikai score-rendszer ismeretében a döntően új típusú kemoterápiás kombinációk, amelyek L-aszparaginázt és platinát tartalmaznak, irradiációval kiegészítve javíthatják ennek a rendkívül rossz gyógyulási hajlamú betegcsoportnak a túlélését.

Anyagi támogatás: A szerzők anyagi támogatásban nem részesültek.

Szerzôi munkamegosztás: A kéziratot B. A. és P. K. írta, a kezelésekben, az adatok összegyưjtésében és azok rendelkezésre bocsátásában a többi szerző vett részt. A cikk végleges változatát valamennyi szerző elolvasta és jóváhagyta.

Érdekeltségek: A szerzőknek nincsenek érdekeltségeik.

\section{Köszönetnyilvánítás}

A szerzők köszönetet mondanak a kezelésben részt vevő valamennyi munkatársnak.

\section{Irodalom}

[1] Swerdlow SH, Campo E, Harris NL, et al. WHO classification of tumours of haematopoietic and lymphoid tissues. IARC, Lyon, 2008.

[2] Swerdlow SH, Campo E, Pileri SA, et al. The 2016 revision of the World Health Organization (WHO) classification of lymphoid neoplasms. Blood 2016; 127: 2375-2390.

[3] Tse E, Kwong YL. How I treat NK/T-cell lymphomas. Blood 2013; 121: 4997-5005.

[4] Vose J, Armitage J, Weisenburger D, International TCLP. International peripheral $\mathrm{T}$-cell and natural killer/T-cell lymphoma study: pathology findings and clinical outcomes. J Clin Oncol. 2008; 26: 4124-4130.

[5] Haverkos BM, Pan Z, Gru AA, et al. Extranodal NK/T cell lymphoma, nasal type (ENKTL-NT): An update on epidemiology, clinical presentation, and natural history in North American and European cases. Curr Hematol Malig Rep. 2016; 11: 514-527.

[6] Yamaguchi M, Tobinai K, Oguchi M, et al. Concurrent chemoradiotherapy for localized nasal natural killer/T-cell lymphoma: an updated analysis of the Japan clinical oncology group study JCOG0211. J Clin Oncol. 2012; 30: 4044-4046.

[7] Perry AM, Diebold J, Nathwani BN, et al. Non-Hodgkin lymphoma in the developing world: review of 4539 cases from the International Non-Hodgkin Lymphoma Classification Project. Haematologica 2016; 101: 1244-1250.

[8] Tse E, Kwong YL. The diagnosis and management of NK/T-cell lymphomas. J Hematol Oncol. 2017; 10: 85.

[9] Chim CS, Ooi GC, Shek TW, et al. Lethal midline granuloma revisited: nasal $\mathrm{T} /$ natural-killer cell lymphoma. J Clin Oncol. 1999; 17: 1322-1325.

[10] Kwong YL, Pang AW, Leung AY, et al. Quantification of circulating Epstein-Barr virus DNA in NK/T-cell lymphoma treated with the SMILE protocol: diagnostic and prognostic significance. Leukemia 2014; 28: 865-870.

[11] Yamaguchi M, Kita K, Miwa H, et al. Frequent expression of Pglycoprotein/MDRl by nasal T-cell lymphoma cells. Cancer 1995; 76: 2351-2356.

[12] Wang B, Li XQ, Ma X, et al. Immunohistochemical expression and clinical significance of $\mathrm{P}$-glycoprotein in previously untreated extranodal NK/T-cell lymphoma, nasal type. Am J Hematol. 2008; 83: 795-799.

[13] Tse E, Kwong YL. Nasal NK/T-cell lymphoma: RT, CT, or both. Blood 2015; 126: 1400-1401.

[14] Yang Y, Zhu Y, Cao JZ, et al. Risk-adapted therapy for earlystage extranodal nasal-type NK/T-cell lymphoma: analysis from a multicenter study. Blood 2015; 126: 1424-1432.

[15] Chim CS, Ma SY, Au WY, et al. Primary nasal natural killer cell lymphoma: long-term treatment outcome and relationship with the International Prognostic Index. Blood 2004; 103: 216-221.

[16] Lee J, Suh C, Park YH, et al. Extranodal natural killer T-cell lymphoma, nasal type: a prognostic model from a retrospective multicenter study. J Clin Oncol. 2006; 24: 612-618.

[17] Kim SJ, Yoon DH, Jaccard A, et al. A prognostic index for natural killer cell lymphoma after non-anthracycline-based treatment: a multicentre, retrospective analysis. Lancet Oncol. 2016; 17: 389-400.

[18] NCCN Guidelines T-cell Lymphomas Version I.2017. https:// www.nccn.org/professionals/physician_gls/pdf/t-cell.pdf

[19] Kim SJ, Kim K, Kim BS, et al. Phase II trial of concurrent radiation and weekly cisplatin followed by VIPD chemotherapy in newly diagnosed, stage IE to IIE, nasal, extranodal NK/T-Cell Lymphoma: Consortium for Improving Survival of Lymphoma study. J Clin Oncol. 2009; 27: 6027-6032.

[20] Matsumoto Y, Nomura K, Kanda-Akano Y, et al. Successful treatment with Erwinia L-asparaginase for recurrent natural killer/T cell lymphoma. Leuk Lymphoma 2003; 44: 879-882. 
[21] Jaccard A, Petit B, Girault S, et al. L-asparaginase-based treatment of 15 western patients with extranodal NK/T-cell lympho$\mathrm{ma}$ and leukemia and a review of the literature. Ann Oncol. 2009; 20: 110-116.

[22] Yamaguchi M, Kwong YL, Kim WS, et al. Phase II study of SMILE chemotherapy for newly diagnosed stage IV, relapsed, or refractory extranodal natural killer (NK)/T-cell lymphoma, nasal type: the NK-Cell Tumor Study Group study. J Clin Oncol. 2011; 29: 4410-4416.

[23] Kim SJ, Yang DH, Kim JS, et al. Concurrent chemoradiotherapy followed by L-asparaginase-containing chemotherapy, VIDL, for localized nasal extranodal NK/T cell lymphoma: CISL08-01 phase II study. Ann Hematol. 2014; 93: 1895-1901.

[24] Zhang L, Jiang M, Xie L, et al. Five-year analysis from phase 2 trial of "sandwich" chemoradiotherapy in newly diagnosed, stage IE to IIE, nasal type, extranodal natural killer/T-cell lymphoma. Cancer Med. 2016; 5: 33-40.
[25] Wang L, Wang ZH, Chen XQ, et al. First-line combination of GELOX followed by radiation therapy for patients with stage IE/IIE ENKTL: An updated analysis with long-term follow-up. Oncol Lett. 2015 ; 10: 1036-1040.

[26] Kwong YL, Kim WS, Lim ST, et al. SMILE for natural killer/Tcell lymphoma: analysis of safety and efficacy from the Asia Lymphoma Study Group. Blood 2012; 120: 2973-2980.

[27] Yhim HY, Kim JS, Mun YC, et al. Clinical outcomes and prognostic factors of up-front autologous stem cell transplantation in patients with extranodal natural killer/T cell lymphoma. Biol Blood Marrow Transplant. 2015; 21: 1597-1604.

(Bakos Annamária dr., Szeged, Korányi fasor 6., 6721 e-mail: drbakos.annamaria@gmail.com)

\section{Rácz Károly Endokrinológiai Továbbképző Tanfolyam Budapest, 2017. november 30. - december 2. NOVOTEL Centrum, 1088 Budapest, Rákóczi út 43-45.}

\section{Köszöntő}

A Semmelweis Egyetem II. Belgyógyászati Klinikája és a Magyar Endokrinológiai Társaság közös szakmai fóruma, az Endokrinológiai Továbbképző Tanfolyam ebben az évben 13. alkalommal kerül megrendezésre. Az eddigi 12 tanfolyam fő szervezője Dr. Rácz Károly professzor úr volt. Sajnálatosan korai halála miatt ez lesz az első olyan tanfolyam, amit a professzor úr részvétele nélkül kell megrendeznünk. Emlékének adózva a tanfolyamot mostantól

Rácz Károly Endokrinológiai Továbbképző Tanfolyamnak nevezzük.

Az eddigi évek sikeres tanfolyamainak hagyományát folytatva a tanfolyam fő céljának továbbra is a korszerü, a klinikai gyakorlatban is használható ismeretek átadását tekintjük. A gyakori betegségekre helyezzük a fő hangsúlyt e betegségek felismerése és kezelése terén, de több ritka, érdekes kórkép bemutatását is tervezzük. Az endokrinológusok mellett számítunk a családorvosok, belgyógyászok, gyermekgyógyászok, szülész-nőgyógyász szakorvosok és mindazon kollégák részvételére, akik az endokrinológia és anyagcsere-betegségek iránt érdeklödnek.

Több szimpóziumot is tervezünk a korszerü kezelési lehetőségek bemutatása céljából. A tanfolyam végén, hagyományainkhoz híven, tanulságos eseteken keresztül mutatjuk be az endokrinológia szépségeit. A tanfolyam kreditpontos és tesztvizsgával zárul.

A továbbképző tanfolyam orvosok részére PTE ÁOK/2017.II/00038-es kódszámon akkreditált. Sikeres tesztírás esetén az orvos résztvevők 42 kreditpontot szerezhetnek. A kreditpontok az OFTEX portálokon feltüntetett szakképesítéseknél szakma szerinti kötelező pontszámként kerülnek jóváírásra.

Reméljük, hogy a Rácz Károly Endokrinológiai Továbbképző Tanfolyam résztvevőiként üdvözölhetjük Önöket.

Kollegiális üdvözlettel:

$$
\text { Dr. Igaz Péter }
$$

Dr. Tóth Miklós

a tanfolyam szervezői

Tudományos információ:

\section{Dr. Igaz Péter}

egyetemi tanár

Semmelweis Egyetem, Általános Orvostudományi Kar, II. Belgyógyászati Klinika

E-mail: igaz.peter@med.semmelweis-univ.hu

\section{Technikai szervezö:}

Convention Budapest Kft. Zimonyi Viktória

1036 Budapest, Lajos u. 66.

Fax: (06 1) 2990187 | Tel./fax: (06 1) 2990184

E-mail vzimonyi@convention.hu

További információk a www.convention.hu honlapon.

\author{
Dr. Tóth Miklós \\ egyetemi tanár \\ Semmelweis Egyetem, Általános Orvostudományi Kar, \\ II. Belgyógyászati Klinika \\ E-mail: toth.miklos@med.semmelweis-univ.hu
}

